\title{
Applications of digital outcrop models: two fluvial case studies from the Triassic Wolfville Fm., Canada and Oukaimeden Sandstone Fm., Morocco
}

\author{
XAVIER M. T. VAN LANEN ${ }^{1 *}$, DAVID HODGETTS ${ }^{1}$, \\ JONATHAN REDFERN ${ }^{1}$ and IVAN FABUEL-PEREZ ${ }^{i, 2}$ \\ ${ }^{1}$ School of Earth, Atmospheric and Environmental Sciences, University of Manchester, Manchester, UK \\ ${ }^{2}$ ExxonMobil House, Ermyn Way, Leatherhead, Surrey, UK
}

\begin{abstract}
The application and benefits of employing digital outcrop models (DOMs) are discussed using two Triassic fluvial case studies to demonstrate data collection and integration methods. Developments in data analysis techniques are examined to demonstrate their utility for collecting meaningful and reliable statistical information needed to build realistic stochastic reservoir models. To establish a significant geostatistical dataset a large number of accurate observations are required. It is difficult to get the necessary statistics using subsurface data alone, due to the limited resolution and/or areal coverage of respectively seismic and well data. Outcrop studies are, therefore, commonly utilized to provide analogue statistical information (e.g. channel width, length, thickness and thickness vs. width ratio). Traditional data collection methods used in the field are however largely restricted to areas with (easy) physical access, or using remote observations with limited accuracy, such as photographic methods.

Digital data collection techniques such as LiDAR (Light Detection and Ranging) and differential GPS allow more accurate measurements, as well as from previously inaccessible locations, to be taken of sedimentary architecture. The technique generates much larger volumes of measurements, as the area from which accurate data can be extracted is increased. This offers a more meaningful statistical dataset, hence reducing uncertainty in the final reservoir model.

Both case studies, the Oukaimeden Sandstone Formation (OSF), Morocco and Wolfville Formation, Canada, are from Late Triassic braided fluvial systems. The OSF dataset has been used to illustrate how geometric information of channel width versus thickness relationships (W:T) are collected using a projection plane technique. The results show W:T variations between 3.49:1 in the Lower Oukaimeden member, 1.54:1 in the Middle Oukaimeden member and 3.75:1 in the Upper Oukaimeden member, demonstrating the observed architectural evolution of the fluvial system. The Wolfville Formation case study shows how DGPS in combination with LiDAR data has been used to more accurately map faults to obtain statistical information on fault orientation $(\mathrm{NE}-\mathrm{SW})$ and length $($ mean $=38.3 \mathrm{~m}$ and median $=18.2 \mathrm{~m})$. Another applied analysis technique utilizes a facies classified point-cloud to aid surface correlations between sedimentary logs and construct a log based correlation panel from which estimates of facies frequencies are derived. Copyright (C) 2009 John Wiley \& Sons, Ltd.
\end{abstract}

Received 31 July 2009; accepted 6 October 2009

KEY WORDS digital outcrop model; geostatistical data analysis; braided fluvial systems; Triassic; Canada; Morocco

\section{INTRODUCTION}

Braided fluvial systems form important reservoirs in many oil and gas provinces around the world (Martin 1993), with Triassic examples common in the North Sea Basin. Within these often-complex reservoirs, fluid distribution and flow are ultimately controlled by the architecture of the depositional system and the internal fabric and geometry of the sedimentary bodies (North and Prosser 1993). It is, therefore, essential to define the variability and geological

\footnotetext{
* Correspondence to: X. M. T. van Lanen, School of Earth, Atmospheric and Environmental Sciences, University of Manchester, Oxford Road,
} Manchester, M13 9PL, UK. E-mail: xavier.van-lanen@postgrad.manchester.ac.uk 
discontinuities in these systems to accurately characterize the reservoir and consequently be able to better understand and predict fluid distribution and flow (Alexander 1993; North and Prosser 1993; Doherty et al. 2005).

However, in most oil and gas fields the available subsurface geological data are far from optimal. Seismic reflection data can only resolve the large-scale architecture, and well data provides a widely spaced dataset that describes less than $0.1 \%$ of the reservoir (North and Prosser 1993). Hence, in the majority of oil and gas fields the available data offers little information on the architecture and spatial relationship (e.g. vertical stacking and lateral continuation) of sedimentary bodies, which makes any geological model of the subsurface reservoir highly interpretive.

Valuable additional insight in the understanding of the reservoir architecture may be provided through direct observations from experimental simulations (e.g. flume tanks) and analysis of modern braided fluvial systems, as well as their ancient outcrop equivalents (Bristow and Best 1993; Grammer et al. 2004). Outcrops have been utilized most frequently as analogues to bridge the resolution gap between seismic and well data, providing the ability to study depositional systems with similar characteristics to subsurface reservoirs at a wide range of scales ( $\mathrm{km}$ to $\mathrm{mm}$ ), and offering three-dimensional accessibility and better data continuity. The traditional methods of observation are, however, largely paper-based for both data collection and interpretation, which provide predominantly qualitative data (Jones et al. 2004; McCaffrey et al. 2005). There are limitations in how this abundant descriptive data, that lacks a spatial attribute (Miall and Tyler 1991), can be utilized in reservoir models as an aid to geostatistical modelling (Bryant and Flint 1993; North and Prosser 1993; Caers and Zhang 2004).

Advances in the last decade in the development of cost efficient and portable digital field tools, such as differential global positioning system (DGPS) and terrestrial scanning LiDAR have provided new equipment that allows rapid acquisition of accurate spatial data from outcrops (Bellian et al. 2005; Pringle et al. 2006). The digital field tools make it possible to build a spatial framework and quantify the outcrop data by connecting the geological measurements and interpretations to their correct geographic position. As such the resulting digital outcrop models (DOMs) enable the capture of valuable numerical information to describe the complex geological heterogeneity of the outcrop (Verwer et al. 2007).

The use of digital field techniques is becoming a more common tool to aid fieldwork and some powerful applications have been demonstrated in recent studies, for example in sedimentological and structural studies (Hodgetts et al. 2004; Verwer et al. 2004b; Adams et al. 2005; Labourdette and Jones 2007; Phelps and Kerans 2007; Olariu et al. 2008; Phelps et al. 2008; Fabuel-Perez et al. 2009a; Hodgetts 2009; Verwer et al. 2009a; Verwer et al. 2009b; Wilson et al. 2009) as well as in earth surface process (Wawrzyniec et al. 2007; McCormick et al. 2008) and ichnology (Bates et al. 2008). Work has further focussed on how the digital data can best be captured and visualized, and in quantifying uncertainties inherent in the datasets (Bond et al. 2007; Enge et al. 2007; Verwer et al. 2007; Buckley et al. 2008). Research on the analysis of spatial datasets and how to utilize their full potential for geostatistical applications have, however, made less progress and need to be addressed (Verwer 2008).

In this paper, two case studies of Late Triassic braided fluvial systems are presented to illustrate how the traditional and digital field data have been collected and integrated to produce DOMs. In addition, the applications and benefits of DOMs are discussed and how novel developments in analysing techniques aid in better utilizing the full digital datasets to obtain geostatistical information and improve our understanding of these fluvial systems.

\section{GEOLOGICAL SETTING OF CASE STUDIES}

The case studies are located in two Early Mesozoic half grabens, the Fundy Basin in Nova Scotia, Canada, and the Central High Atlas Basin in Morocco (Figure 1a), which are part of a series of rift basins that formed as a consequence of extensional tectonics related to the opening of the North Atlantic Ocean (Figure 1b) (Manspeizer et al. 1978; Manspeizer 1988; Petit and Beauchamp 1986; Wade et al. 1996). The sediments filling the basins are characterized for the most part by non-marine siliciclastics which are capped by basalt flows (Olsen 1997). In the following section brief reviews are given of the stratigraphic framework of both Carnian aged case studies and their stratigraphic relationship is shown in Figure 2. 

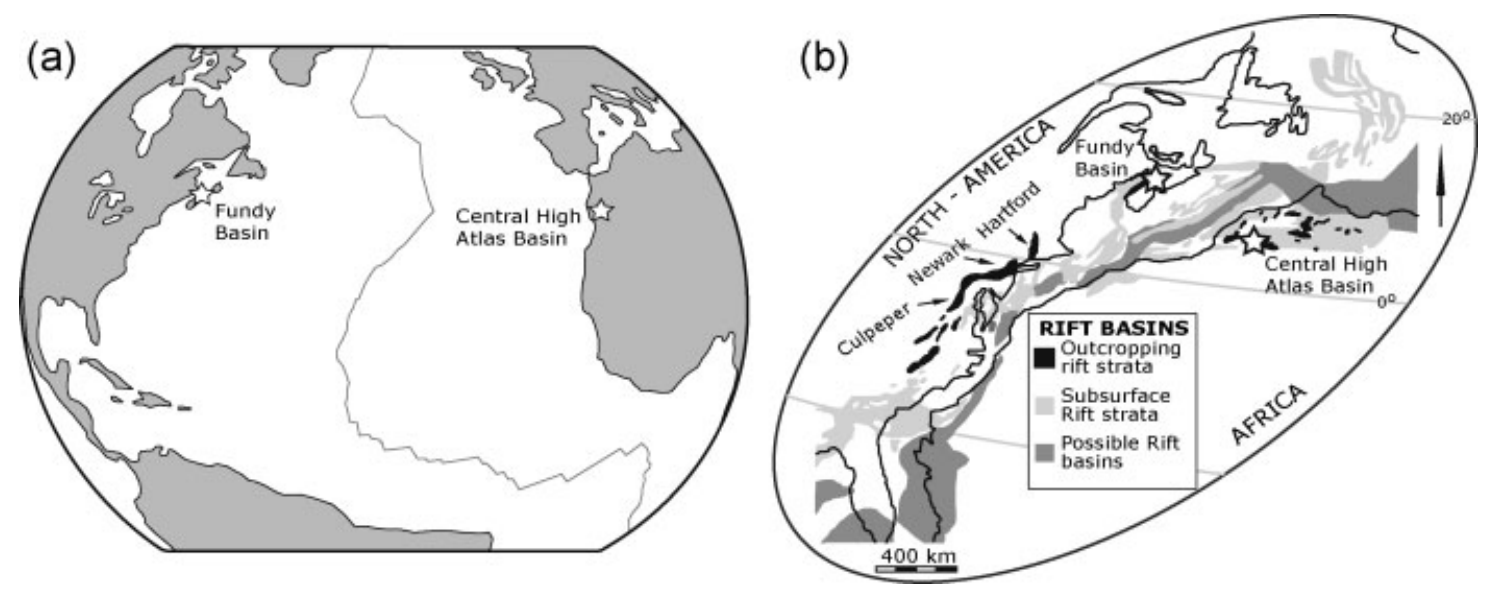

Figure 1. (a) Location map of the Canadian Fundy Basin Wolfville Formation and Moroccan Central High Atlas Basin Oukaimeden Sandstone Formation datasets placed in a global context, showing relative positions on either side of the Atlantic Ocean. (b) Distribution of the exposed and subsurface Triassic rift basins along the Atlantic Margin in their palaeogeographic position for the Carnian $(\sim 225 \mathrm{Ma})$. Highlighted are several exposed basins in Eastern North America and Morocco. Modified from Olsen (1997).

\subsection{The Central High Atlas Basin}

The Permo-Triassic Central Basin Facies (Mattis 1977), crops out in the Central High Atlas Basin (Figure 3) It can be subdivided into six formations, F1 to F6, based on lithology and major discontinuities (Mattis 1977; Benaouiss et al. 1996). The studied succession, the Oukaimeden Sandstone Formation (OSF) (F5), is dated as Middle Carnian in age, based on palynofloral assemblages (Biron and Courtinat 1982). It comprises a dominantly sandy bedload braided fluvial system and can be divided informally into lower, middle and upper members, each having distinctive lithofacies and showing an evolution in architectural style (Fabuel-Perez et al. 2009b).

The Lower Oukaimeden member represents an ephemeral fluvial system consisting of in-channel stacked crossbedded and channel bar sandstones alternating with laterally continuous, finer grained abandonment facies sediments. The Middle Oukaimeden member architectural style records fluvial rejuvenation and a switch to

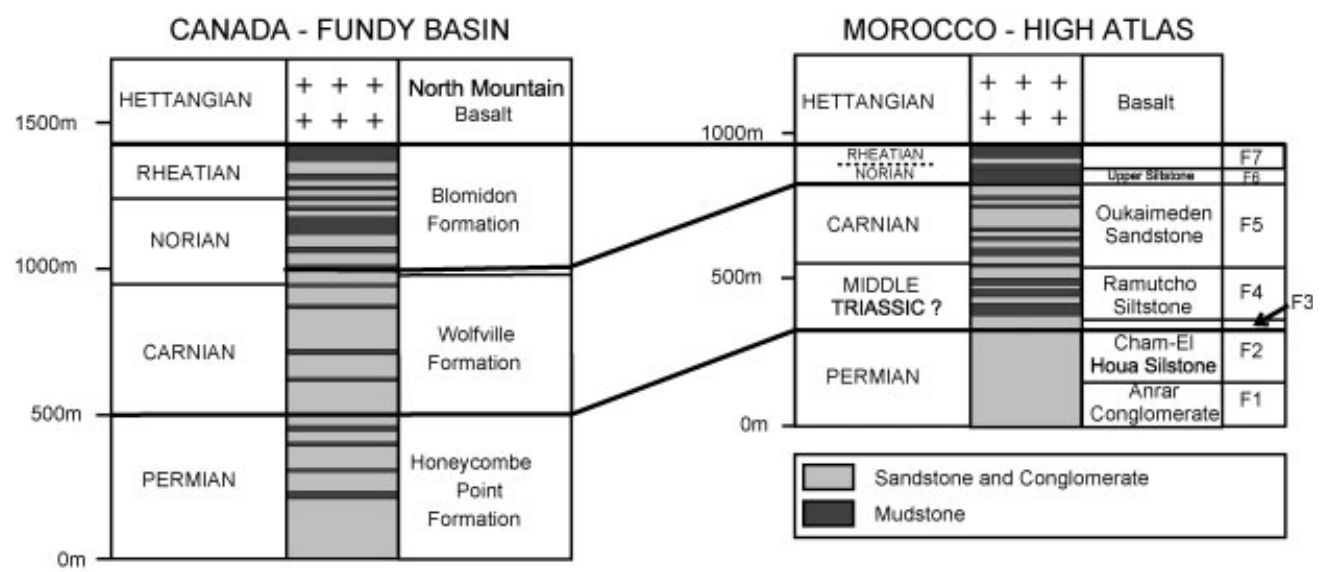

Figure 2. Simplified comparative stratigraphy of the Fundy Basin and Central High Atlas Basin, comparing the Permian and Triassic sections. Values shown are average thickness. Modified from Olsen et al. (2000). 


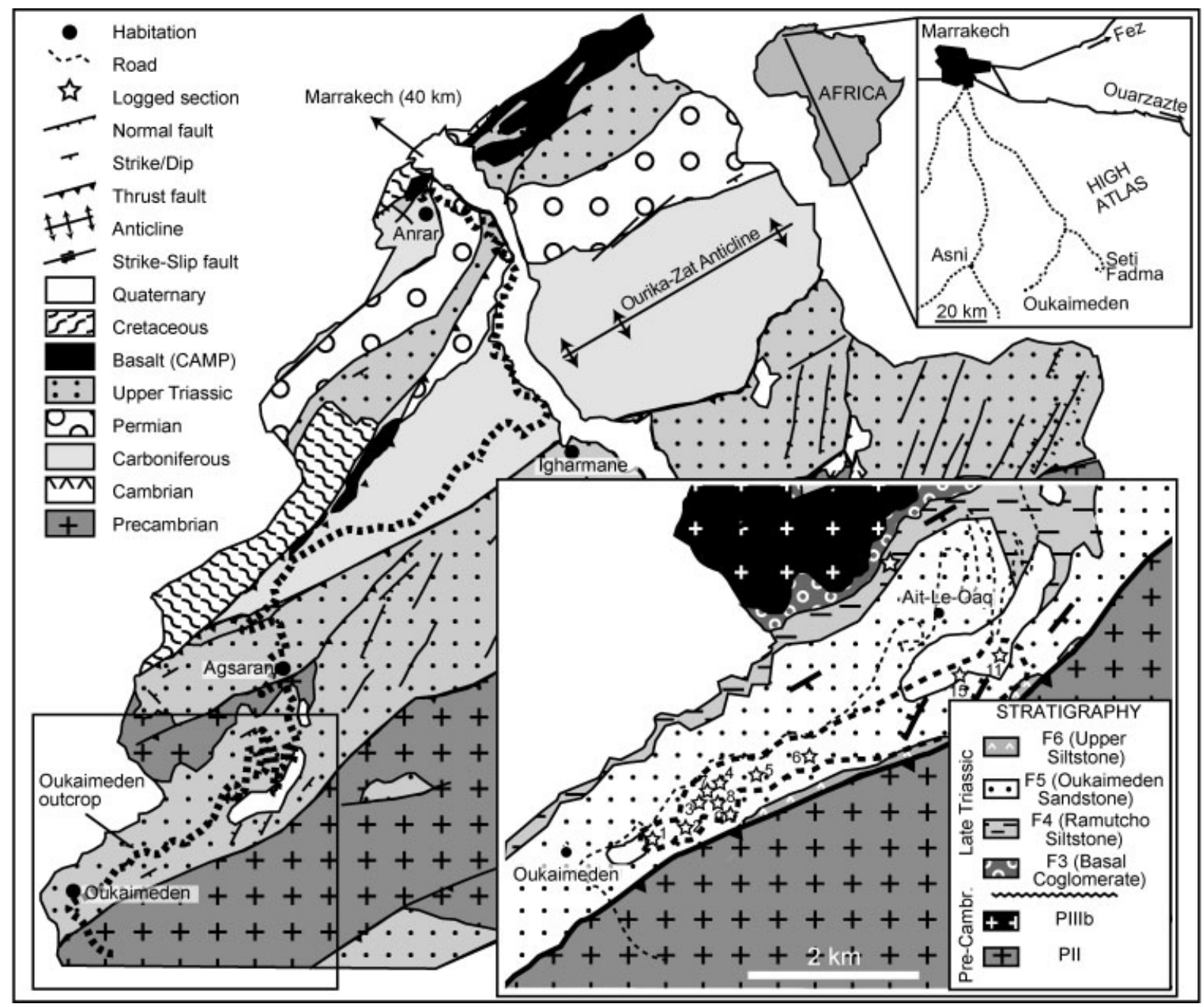

Figure 3. Location map and simplified geological map of the Central High Atlas showing the study area in the Ourika-Oukaimeden Valley (modified from Taj-Eddine and Pignone 2005). The inset shows a detailed view of the study area and position of the different logged sections.

perennial conditions. It comprises vertical stacked amalgamated channel and channel bar deposits and is sandstone dominated, with a major decrease in preserved finer grained abandonment facies sediments compared to the Lower Oukaimeden member. The Upper Oukaimeden member contains finer grained abandonment facies sediments interbedded with sandstones deposited in braided fluvial channels and channel bars, and subordinate aeolian dune sandstones. The latter is interpreted to record a return to an ephemeral system, and a switch to more arid conditions. Towards the top of the upper member isolated outcrops of tidally-influenced deposits are present, indicating the first marine incursion into the basin.

\subsection{The Fundy Basin}

The Fundy Basin in Nova Scotia, Canada contains coeval Permo-Triassic deposits (Figure 4) (Olsen 1997). In the Minas Sub-basin the Wolfville Formation records the initial syn-rift phase, with Triassic continental sediments unconformably overlying Carboniferous and older metasedimentary and igneous rocks of the Meguma Terrane 


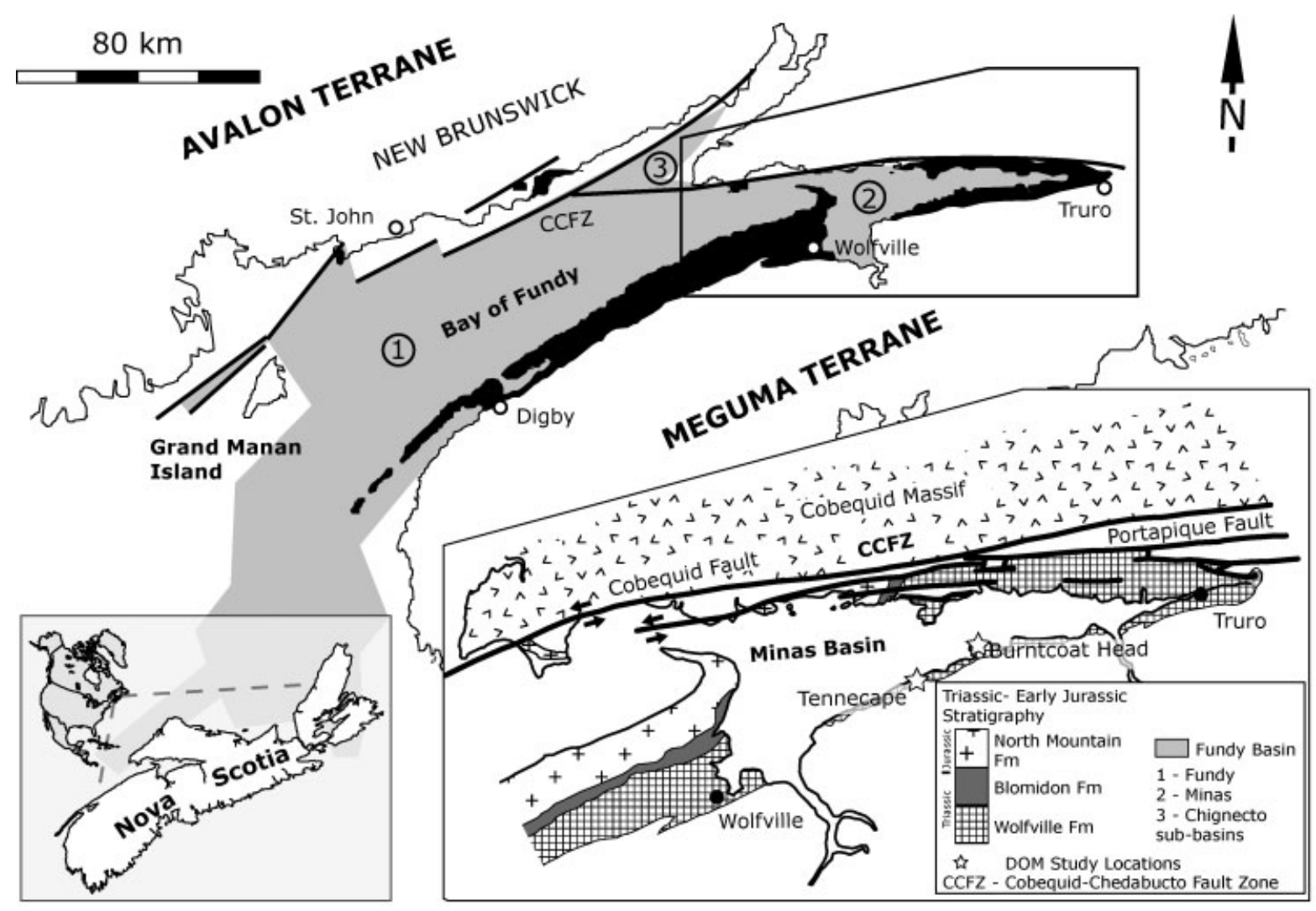

Figure 4. Location map of the Fundy Basin showing the outline of the basin and the position of the sub-basins: 1. Fundy Sub-Basin 2. Minas Sub-Basin and 3. Chignecto Sub-Basin. The inset shows a simplified geological map and the location of the main study areas for digital outcrop study: Tennecape (Lower Wolfville Fm.) and Burntcoat Head. (Middle Wolfville Fm.). Modified from Olsen et al. (1989).

(Wade et al. 1996). Although the age range of the Wolfville Formation is uncertain, most of the formation is believed to be not older than Carnian in age based on mollusc, reptile and amphibian remains (Olsen et al. 1989). The studied succession comprises the lower and middle part of the Wolfville Formation. It consists of conglomerates and coarse to fine-grained fluvial sandstones (Hubert and Forlenza 1988; Leleu et al. 2009) aeolian dune sandstones (Hubert and Mertz 1980, 1984) and alluvial fan conglomeratic deposits (Hubert and Mertz 1984).

Where it crops out along the southern shore of the Minas Basin, the Lower Wolfville Formation has a thickness of $115 \mathrm{~m}$ (Leleu et al. 2009) and is exposed over a $27 \mathrm{~km}$-long nearly continuous profile. The basal unit comprises alluvial fan deposits $(<20 \%)$ that fill the palaeotopography, overlain by pebble-dominated fluvial sediments $(>80 \%)$. The sequence is capped by finer grained facies and mudstones of an ephemeral lake-margin facies association (Leleu et al. 2009). The large-scale fluvial architecture in the lower part records repetitive cycles of multi-storey channel belts bound by fining-upwards sedimentary cycles (Leleu et al. 2009).

The conformable Middle Wolfville Formation overlies the lake-margin deposits. It crops out on the southern and northern shore of the Minas Basin and has an estimated maximum thickness of $350 \mathrm{~m}$. The middle Wolfville consists of sandy bedload dominated braided fluvial deposits (90\%) and to a lesser extent of fine-grained abandonment facies sediments (10\%). The middle part comprises two main fluvial architectural stacking patterns. At the base multilateral stacked-channel bodies with little preservation of fine-grained floodplain facies occur, evolving upwards to multi-storey stacked channel bodies that form channel belt complexes intercalated with thicker floodplain deposits. 


\section{DIGITAL OUTCROP MODELS (DOM)}

The descriptive sedimentological and stratigraphic analysis of both Triassic basins provide valuable reservoir analogues. However, to be able to extract quantitative information (e.g. channel dimensions, stacking patterns) of the braided fluvial systems a spatial component is required. Digital outcrop studies provide the spatial data necessary to build DOMs which can be analysed in a quantitative matter. In the case studies a similar workflow for the outcrop selection to data collection and processing is used as described in Enge et al. (2007), Verwer et al. (2007) and Buckley et al. (2008), however novel techniques are applied to integrate and analyse the entire collected dataset. In this section, a review is given of the workflow (Figure 5) used for the case studies. As the principles on outcrop selection to data collection and processing are already well addressed, the focus here will be on the developed integration and analysis techniques.

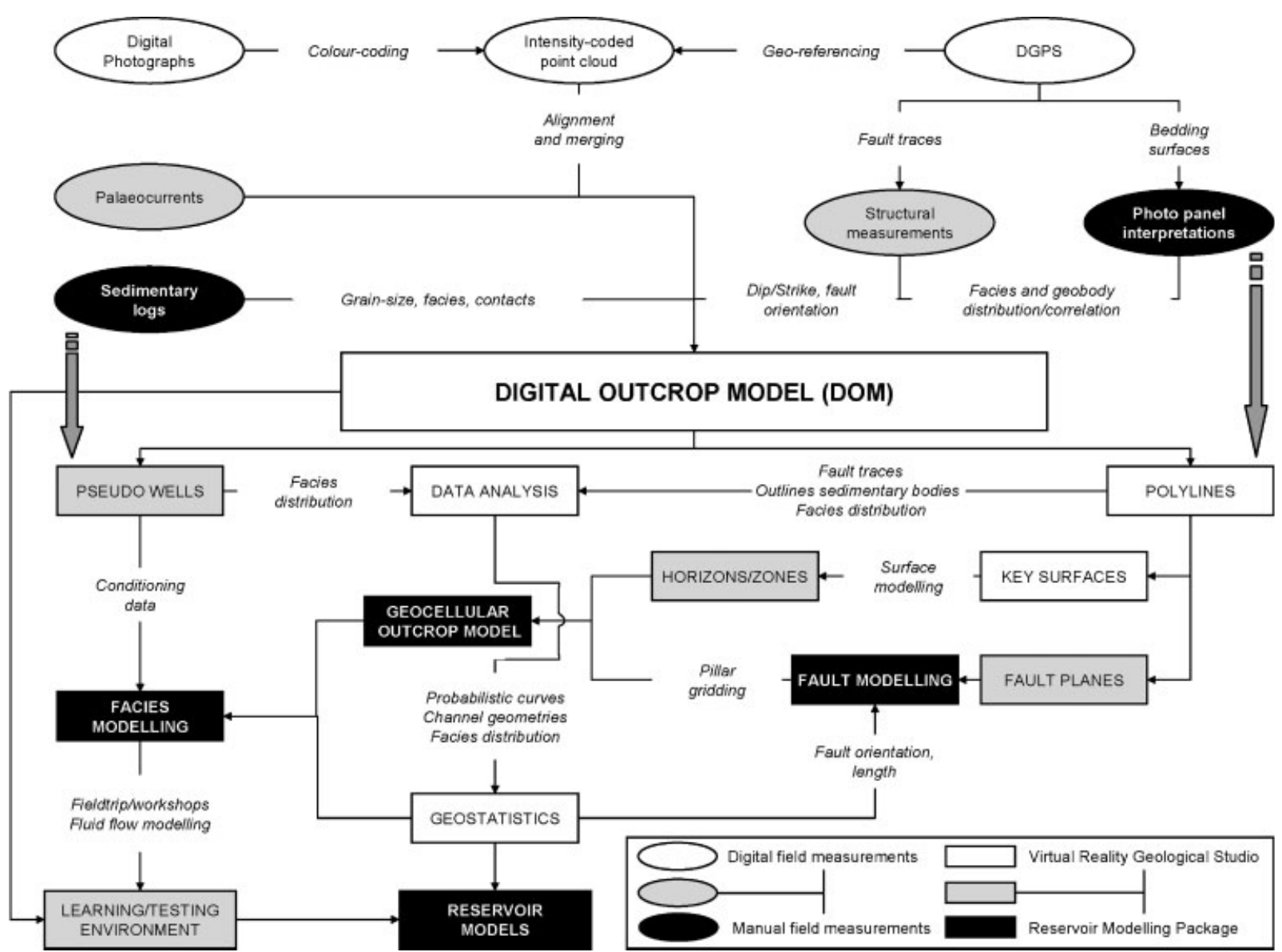

Figure 5. Schematic workflow summarizing the key steps from data selection to collection, integration/processing and analysis of DOMs. The ovals represent input data used to construct DOMs. White ovals correspond to digital acquired field data; black ovals to manual measured field data and shaded ovals where both digital and manual collection methods are used. The rectangles describe the data integration process in order to obtain the geostatistical information and learning environment to aid application in reservoir models. White rectangles represent processes handled in Virtual Reality Geological Studio (VRGS), black rectangles the processing steps carried out in Reservoir Modelling Packages (RMPs) and shaded rectangles the processes that are/can be dealt with in both applications. The italics between the ovals and rectangles indicate the process applied/information used in following step. The thicker shaded arrows show data groundtruthing for quality control. 


\subsection{Data collection}

Data in digital outcrop studies can be collected using several tools such as terrestrial or airborne scanning LiDAR and laser ranging as well as Real Time Kinematic (RTK) or Differential (D) GPS, high-resolution shallow seismic, Ground Penetrating Radar (GPR) and boreholes (Corbeanu et al. 2001; Hodgetts et al. 2004; Jones et al. 2004; Verwer et al. 2004a; Verwer et al. 2004b; Labourdette and Jones 2007; Viseur et al. 2007; Engelkemeir and Khan 2008; Jones et al. 2008a; 2008b; Fabuel-Perez et al. 2009a; Verwer et al. 2009a; 2009b). Valuable additional data (e.g. fault trends, bedding surfaces) can be gained from remote sensing multi-spectral satellite imagery and orthorectified aerial photographs (Verwer et al. 2004b; Wilson et al. 2009).

For optimal results more than one technique should be utilized. Which techniques are chosen or are most suitable is dependant on factors such as duration of study, cost constraints, detail and precision required and the nature (e.g. style and quality) and location (e.g. accessibility) of the outcrop exposure (Jones et al. 2008b). It is therefore essential that besides selecting the right outcrop area for the required sub-surface analogue that the area itself is suitable for the digital field study. The two case studies herein were selected in order to optimize the acquisition (develop and test new integration and analysis techniques) of quantitative data on the stacking pattern, distribution and geometry of the sedimentary bodies and related facies.

\subsection{Hardware}

In both case studies a Riegl LMS-Z420i terrestrial scanning LiDAR (Figure 6a) and Trimble Pro XR DGPS system (Figure 6b) were utilized. The terrestrial LiDAR scanner makes rapid continuous measurements over the entire outcrop face to record $\mathrm{x}, \mathrm{y}, \mathrm{z}$ positions and laser intensity values of the outcrop face related to the scanner position (Figure 6c). The laser intensity values depend on the reflectivity of the outcrop face (e.g. rock type, weathering) and distance between outcrop and scanner. In addition a DGPS receiver and calibrated camera are integrated with the scanner. They record respectively the correct geospatial position to allow geo-referencing of the dataset and digital images of the outcrop face to add a colour component to the LiDAR dataset (Figure 6d). The DGPS equipment further allows the collection of point data by recording field observations (e.g. physically tracing faults and bedding surfaces) while in the field to complement the interpretations from the LiDAR dataset.

\subsection{Creating DOMs}

After post-processing, the outcrop data can be integrated into a DOM to be analyzed. Detailed descriptions of LiDAR and DGPS data processing, such as geo-referencing and merging and cleaning of point-clouds, can be found in Bellian et al. (2005) and Buckley et al. (2008). The integration of the mixture of collected geological data and analysis of these DOMs are however not straightforward. Most commonly utilized software packages are designed to handle subsurface data for primarily modelling purposes rather than working with outcrop data, and consequently have their limitations. Even though several intuitive methods for handling the data in Reservoir Modelling Packages (RMPs) have been developed (Enge et al. 2007; Verwer et al. 2007) limits in data manipulation remain, and appropriate analysis techniques are not available. In order to overcome the limitations of data analysis using existing RMPs, the case studies utilize Virtual Reality Geological Studio (VRGS), a University of Manchester in-house developed platform for geoscientists (Hodgetts et al. 2007), to integrate, visualize, interpret and analyze outcrop data in DOMs.

Stage 1 in building the DOMs is to construct the stratigraphic and structural framework, generally using Digital Elevation Models (DEMs) derived from LiDAR datasets as a template. The observed stratal horizons and fault planes are traced when possible directly in the field using DGPS equipment and/or picked remotely using the LiDAR datasets. Photo-panel correlations (Figure 7a) and field measurements are used as groundtruth for the picked surfaces and planes (Figure 7b). The visual inspection tools in VRGS can significantly enhance and expand the photo-panel correlations and field measurements and be used to quality check the field data. In VRGS the integrated outcrop data and interpretations can be toggled on and off separately and viewed at different scales and 


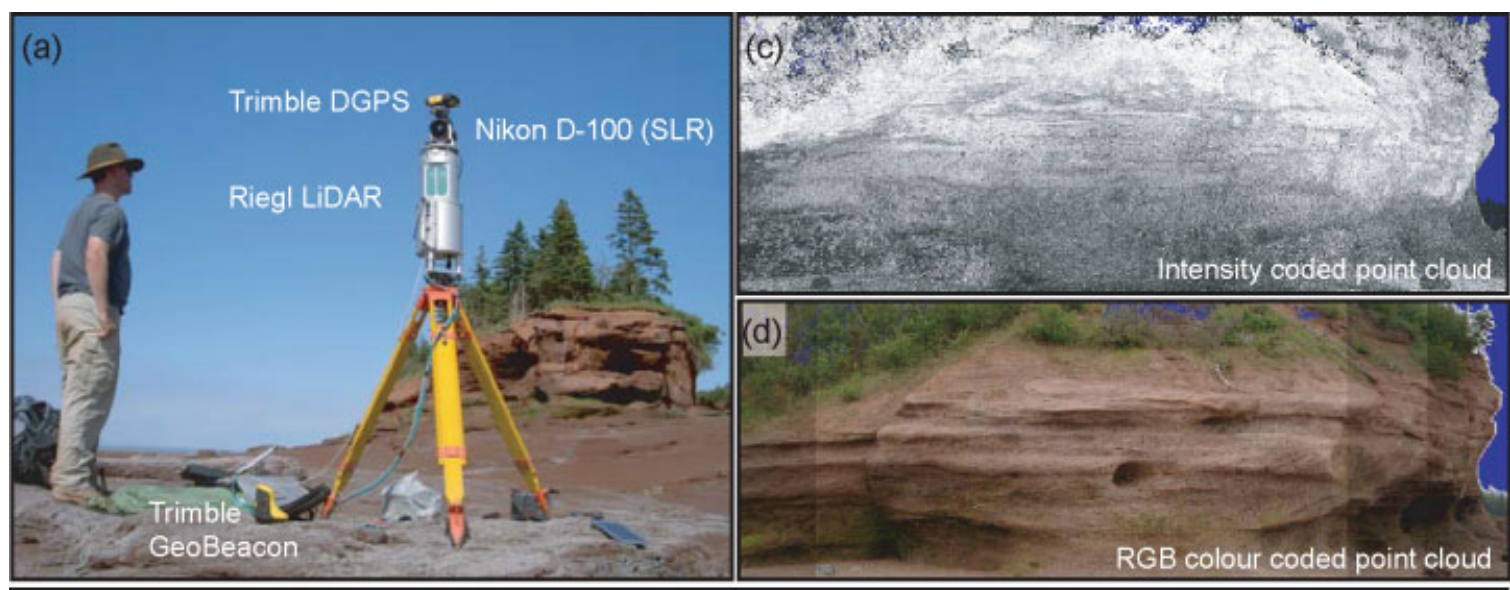

(b)

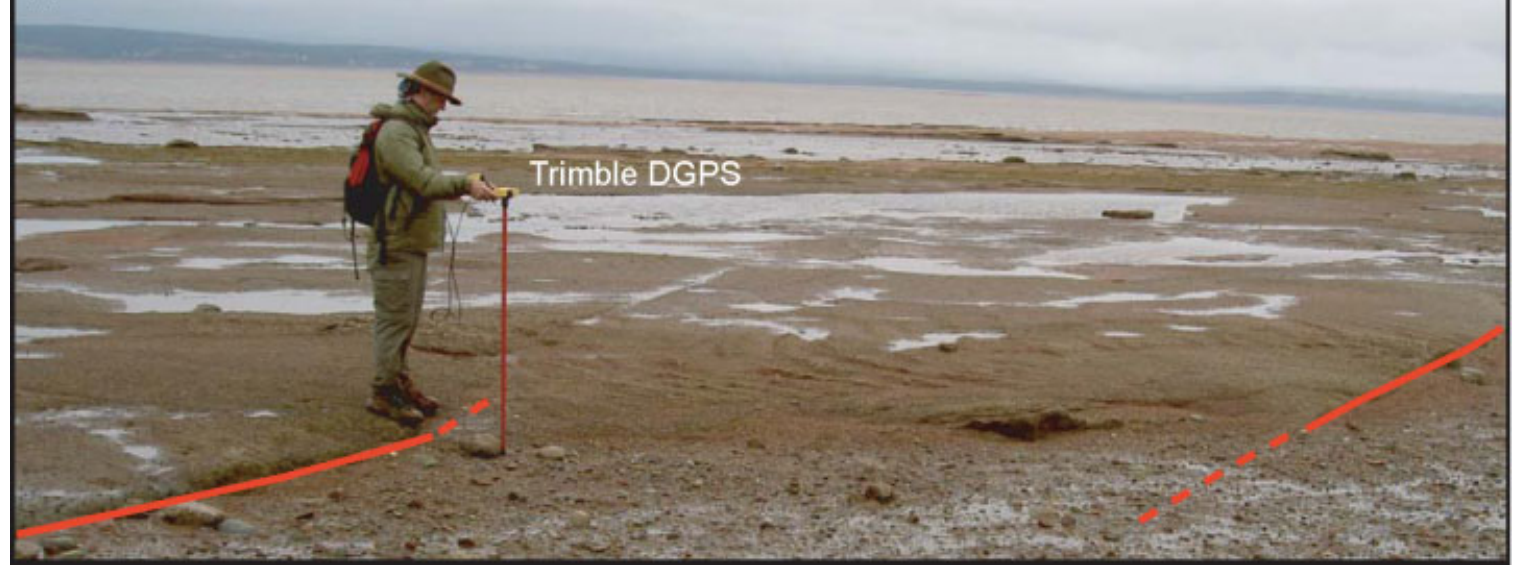

Figure 6. (a) The Riegl LMSZ420i terrestrial laser scanner used for collecting both the majority of the Moroccan Oukaimeden Sandstone Formation and Canadian Wolfville Formation datasets. (b) Trimble Differential (D) GPS equipment used to map features on the wave-cut platform to groundtruth the Canadian Wolfville Formation dataset in addition to the LiDAR dataset. In the photo fault segments on the wave-cut platform of the Tennecape study area are mapped out to their full extend. (c) The raw data from the LiDAR dataset where the point-cloud shows a specific intensity (reflectivity) value for each point. (d) The LiDAR point-cloud can be re-processed using digital photos taken while scanning the outcrop. The RGB values of the digital photos are used to colour-code the point-cloud to make photo-realistic representations of the outcrop, for example to map out key surface.

angles by zooming, panning and rotating the DOM. Those additional views often provide observations from a different perspective (e.g. looking down at the outcrop) and make normally inaccessible areas (e.g. water and canyon flanked exposures and steep cliff sections) available for interpretation. The integration of different kinds of outcrop data in the DOM itself may also lead to new observations. In the Canadian Wolfville Formation case study integrating high-resolution satellite imagery allowed the extension and connection of the individual digital measured fault traces which greatly improved the initial fault model.

Stage 2 incorporates sedimentary logs, structural measurements and palaeocurrent directions into the DOMs (Figure 9a). Structural and palaeocurrent data measured in the field can easily be added in VRGS as point data using either their known spatial location or selecting the measurements position on the LiDAR dataset. The palaeocurrent data can easily be restored in VRGS for structural tilt when required using the integrated structural measurements. Additional structural and palaeocurrent measurements can also be derived from the LiDAR data using an interpretation tool that allows the operator to select three points on a bedding surface or cross-bed foreset to derive respectively strike and dip or flow direction. Care should be taken to guarantee the quality of these remote 

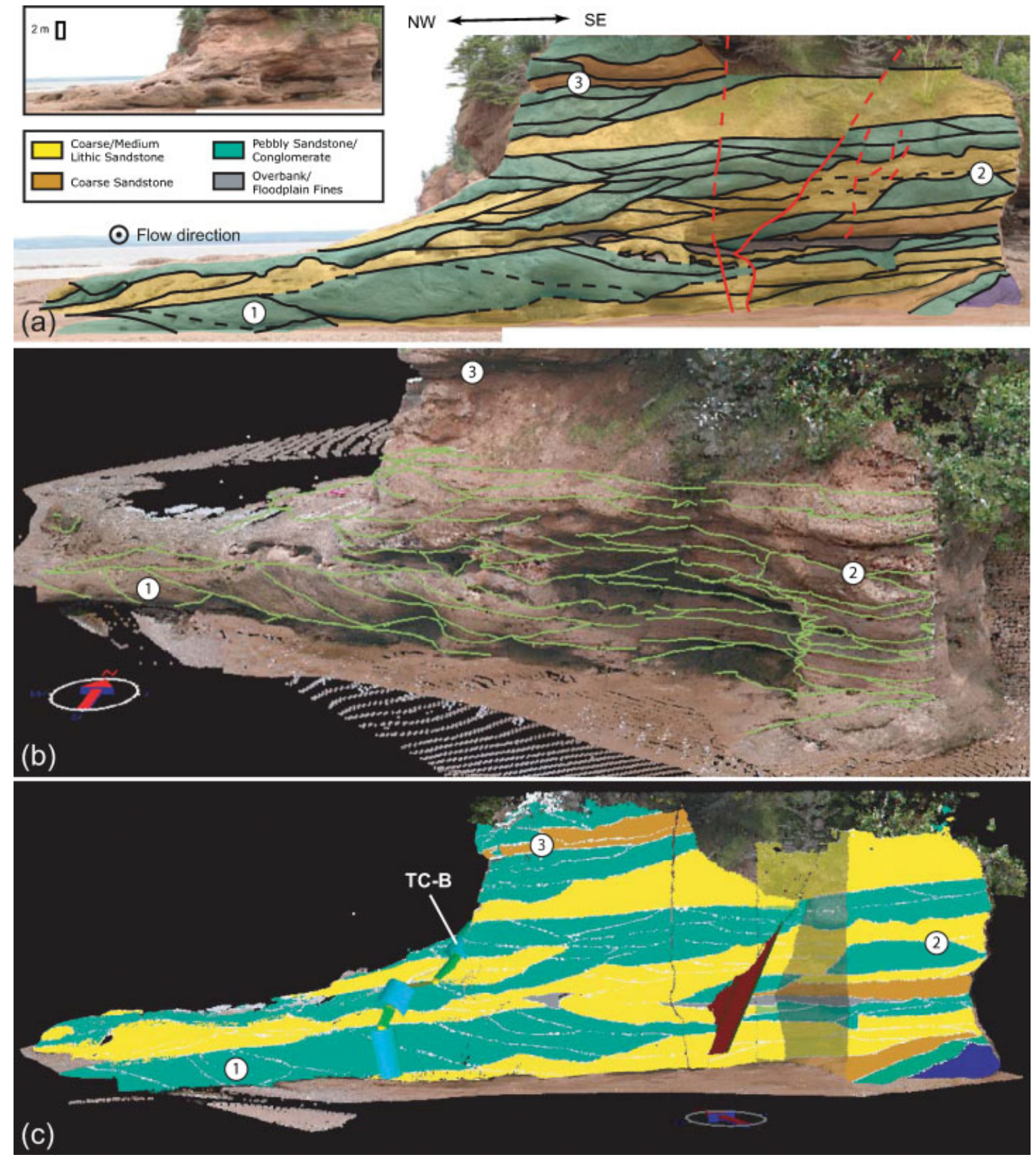

Figure 7. All photographs show the same cliff section in the Tennecape study area (Lower Wolfville Fm.) in a near similar orientations (numbers mark reference points). (a) Top image is the outcrop photograph taken while scanning the outcrop containing hand drawn interpretation of the different facies to show the distribution and surface correlation between sedimentary logs. (b) The image shows a view of the colour-coded LiDAR point-cloud (Figure 6d) in VRGS with the picked surfaces from the interpreted photographs. (c) The lower image shows the point-cloud in VRGS with the digital model re-coloured and classified according to the facies for which the interpreted photograph of Figure 7a is used as groundtruth. Note the digitized sedimentary $\log$ (TC-B) which is attached to the scan image and used to quality check the classified point-cloud. 
measurements, and correlation with manual field-based measurements ensures they are reliable and accurate. Integration of sedimentary logs is undertaken using a tool which allows addition of grainsize, lithology, facies and position of the log trace (e.g. deviation), similar to the well import tool in RMPs. The sedimentary logs can later be easily exported in LAS format, and used as pseudo wells in RMPs to constrain geocellular outcrop models.

Stage 3 is to use the traced or picked stratal horizons to generate three-dimensional surfaces which can later be exported and used in the zonation of the geocellular model. A novel surface building algorithm within the VRGS software uses a combination of the interpreted stratigraphic horizons and structural (dip and strike) information to generate Triangulated Irregular Networks or TIN surfaces (Hodgetts et al. 2007; Wilson et al. 2009). The algorithm provides improved surfaces in areas where no or little conditioning data for the position of the stratigraphic horizon is available by honouring the structural information. In the generation of the subsequent stratigraphically lower and higher surfaces the positions of adjacent surfaces are taken into account to maintain valid thickness and prevent surfaces intersection.

\section{ANALYSIS TECHNIQUES}

After data integration and initial interpretations (e.g. bedding surfaces, fault planes) the DOMs can be used to extract quantitative data. Extracted information, like statistical ranges and distributions of sedimentary geobodies and facies, as well as defining surface geometries (Wilson et al. 2009), can greatly aid the understanding of the area under study. Several selected analysis techniques used in the OSF and Wolfville Formation case studies are described to illustrate the benefits of DOMs in providing additional information to traditional outcrop studies in understanding a depositional system.

\subsection{Oukaimeden Sandstone Formation (OSF)}

In the OSF case study the orientation of the outcrop in relation to the main fluvial palaeocurrent direction significantly complicated extraction of statistical information on the geometry of the channels, as the outcrop face is sub-parallel to palaeoflow. In order to solve this common problem a technique termed 'perpendicular projection plane' was developed. Fabuel-Perez et al. (2009a) demonstrate the use of the technique in detail by which the mapped surfaces and channels and channel bars are projected onto a model generated plane perpendicular to flow direction (Figure 8a). The resulting projection gives the true geometries of channels and channel bars (white lines in Figure $8 \mathrm{a}$ ) for a specific outcrop face orientation and palaeocurrent direction. The technique assumes that palaeocurrents are broadly uniform and the channels linear in nature over the length of the outcrop (Figure 8b). The limited spread of the observed palaeocurrents, $035^{\circ}$ to $097^{\circ}$, with a modal direction of $067^{\circ}$, suggests this is the case for the fluvial system in the OSF case study. There is, however, still some uncertainty in the assumption of linearity given the palaeocurrent spread. To take this uncertainty into account projection planes are created for the modal $\left(067^{\circ}\right)$ as well as the extreme $\left(035^{\circ}\right.$ and $\left.097^{\circ}\right)$ palaeocurrent directions to give the range of possible width versus thickness (W:T) relationships. The range provides a 'most likely' W:T relationships based on the P50 modal and the P10 and P90 W:T relationship for the extreme palaeocurrent measurements. In Figure 8c the W:T data for the modal palaeocurrent direction are plotted for the Lower, Middle and Upper Oukaimeden members. The results show a variation in W:T between the different members. The Lower Oukaimeden member has a W:T of 3.49:1, the Middle Oukaimeden member a W:T of 1.54:1 and Upper Oukaimeden member a W:T of 3.75:1, illustrating the observed evolution of the fluvial architecture over time.

The use of the technique in combination with the DOM allowed far more of the outcrop to be included in the analysis, overcoming the lack of accessibility and problems caused by the orientation of the outcrop, providing a more statistically significant and accurate dataset than would have been possible from direct field observations alone. The statistical results of OSF case study were used to build a stochastic model of the outcrop using Schlumberger PETREL reservoir modelling software and used as a learning environment. 


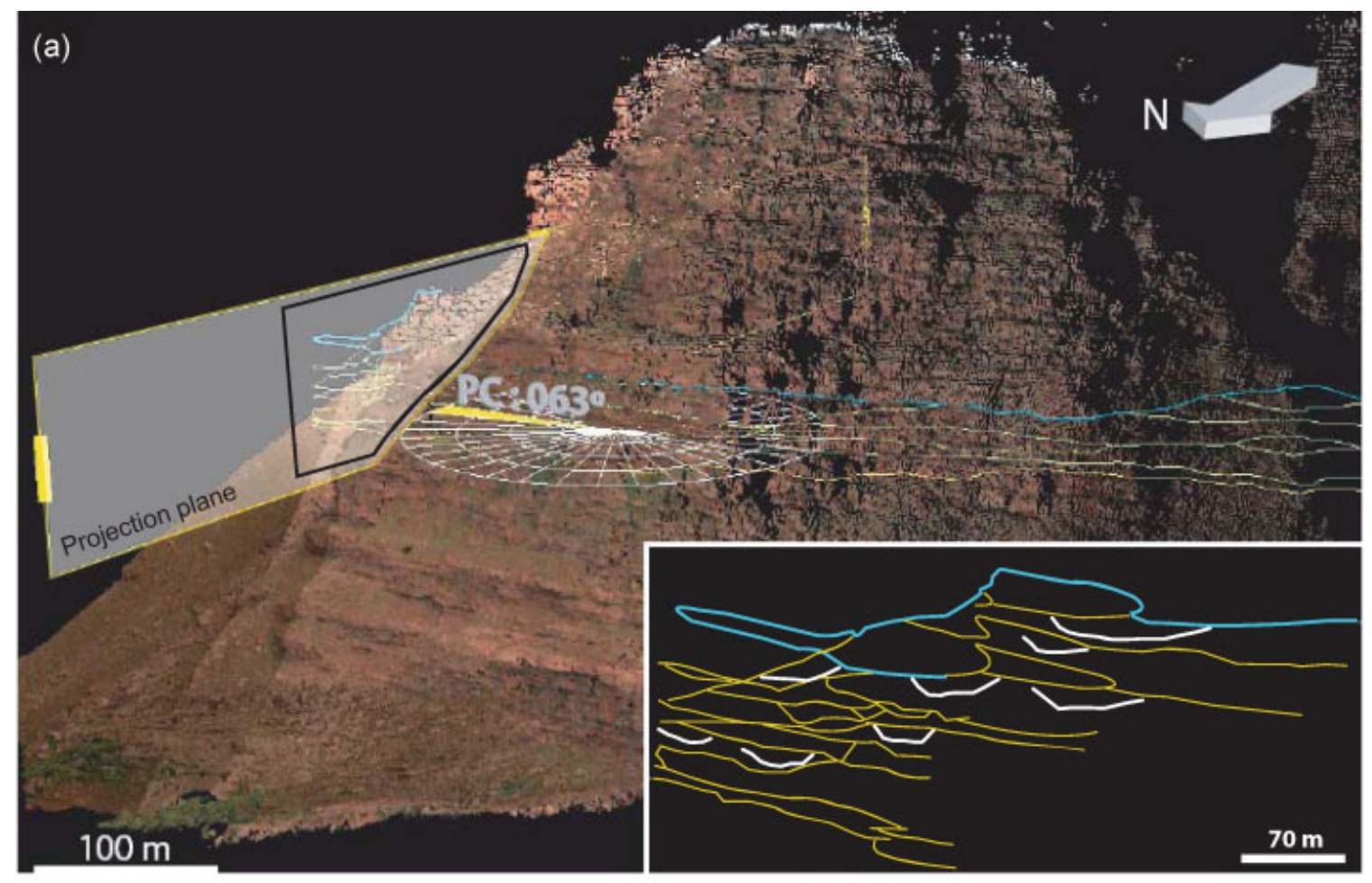

(b)

(c)
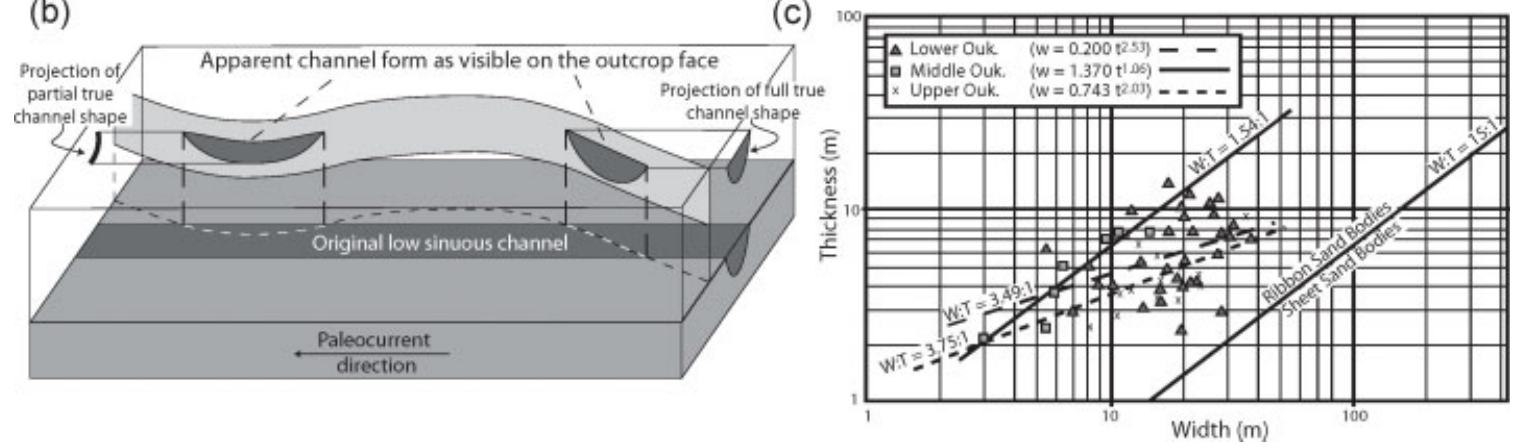

Figure 8. (a) Analysis of sedimentary body dimension from a large Triassic fluvial outcrop of the Moroccan Oukaimeden Sandstone Formation, displaying a view in VRGS to illustrate the use of 'perpendicular projection plane' technique corresponding to a modal palaeocurrent direction $\left(067^{\circ}\right)$. Note how different polylines have been selected (white lines) depending on the observed morphology for true channel geometry calculations. (b) A schematic representation of the problem associated with calculating true channel geometries in an area where the palaeocurrent direction is sub-parallel to the outcrop. The dark shaded areas represent the channel and their apparent form as visible on the outcrop face (light shaded plane), which are projected on planes perpendicular to flow. (c) Width versus thickness dimensions log-log plot based on the measurements of channel forms for a modal palaeocurrent direction $\left(067^{\circ}\right)$. The best fit lines for each dataset show W:T ratios and the empirical power-law equation which relates to width to thickness. A W:T $=15: 1$ line (defined by Friend et al. 1979) which separates between ribbon and sheet sand bodies is added for comparison.

\subsection{Wolfville Formation}

In the Lower Wolfville Formation the DOM has aided in interpreting and analysing the faults, to extract statistical information (e.g. average length, orientations). As mentioned earlier the ability to analyze a DOM from multiple viewpoints allowed individual fault segments to be more accurately correlated and made interpretation of inaccessible areas possible (e.g. at unstable locations of the near vertical cliffs). An overview of the Lower 

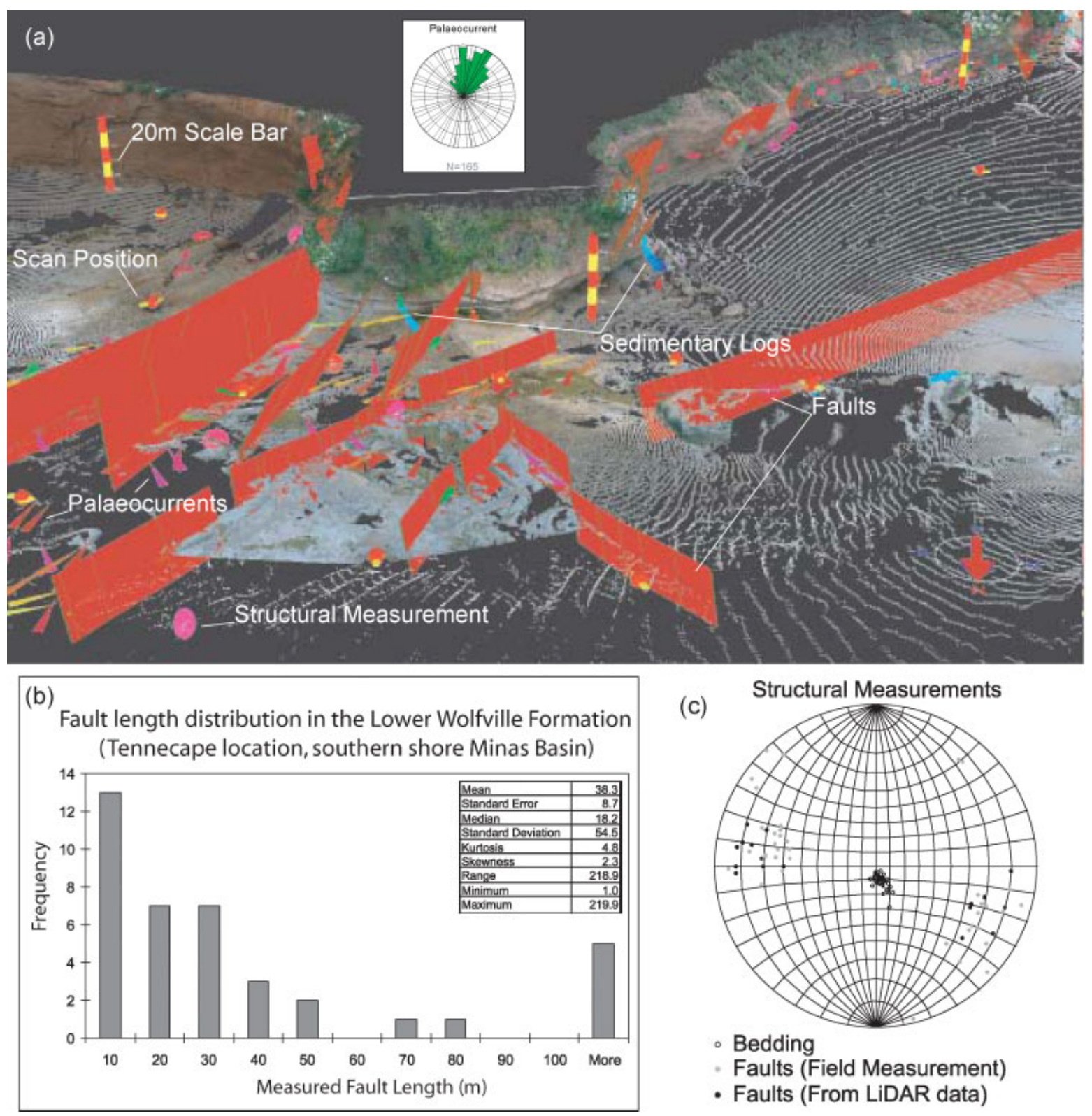

(c)

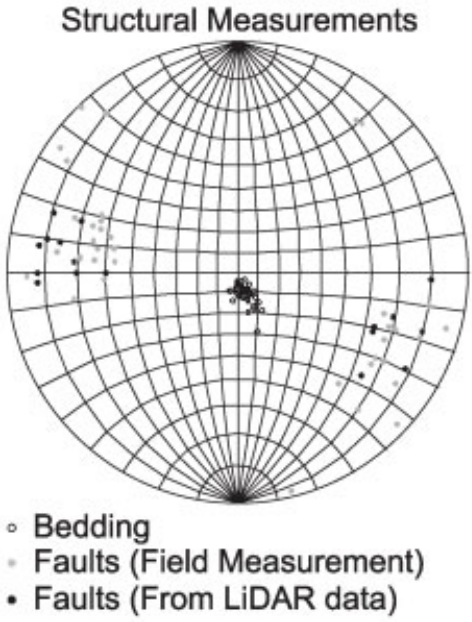

Figure 9. (a) LiDAR dataset view in VRGS of the colour coded point-cloud showing the cliffs and the wave-cut platform of the Canadian Lower Wolfville Formation study area. Different interpretations and data types are labelled on the image, like mapped faults as red planes, scan positions of the LiDAR survey, palaeocurrent and structural measurements, scale bars and sedimentary logs which are attached to the dataset in their correct position. (b, c) Histogram of summary statistics of fault and fracture length distribution and orientations plotted in a stereoplot, all data are derived from DGPS outcrop mapping and interpretation of the LiDAR dataset.

Wolfville Formation dataset, currently containing 39 fault segments, is shown in Figure 9a. The majority of the faults could be traced to their full extent on the wave-cut platform, however some of the cliff-derived faults are represented by a minimum length as no connection with the wave-cut platform was apparent. The faults mainly show minor displacement of $10 \mathrm{~s}$ of $\mathrm{cm}$, and are extensional, with dip to oblique slip. Minor strike-slip displacement has also been observed on some faults. The faults predominantly trend in a NE-SW orientation and minor faulting is observed in a NW-SE orientation, forming conjugate fault sets dipping in opposite directions (Figure 9b). The 
faults range in length from $\sim 1.0$ to $\sim 220 \mathrm{~m}$, with a mean fault length of $38.3 \mathrm{~m}$. However, most of the measured fault lengths are below $20 \mathrm{~m}$ (median $=18.2 \mathrm{~m}$ ) (Figure 9c). The derived statistical information provides input data to steer the fault modelling in RMPs and allows the building of a more optimal fault model.

Another analysis technique applied to the Wolfville Formation dataset makes use of the continuous LiDAR data by classifying the point-cloud for facies and sedimentary bodies to constrain their true three-dimensional distribution. In this method photographs taken while collecting LiDAR data are utilized as the basis for field-based interpretation of facies and sedimentary body distribution (Figure 7a). These interpreted photographs were then digitized and used to re-colour the point-cloud (Facies 7c). The resulting scan images which are classified by facies types provide a deterministic correlation of the horizontal and vertical stacking of facies distribution and variability in their correct spatial relationship. In the DOM these classified scan images can greatly aid the correlation of the sedimentary log data and estimating the percentage composition of facies proportions.

Figure 10a shows a correlation panel for the Lower Wolfville Formation dataset derived from the DOM. Linking the correlation panel data with the classified scan images (Figure 7c), significantly reduced the uncertainty associated with correlations based on log data alone. The outcrop has a relatively steep regional dip making correlations over large distances $(>100 \mathrm{~m}$ ) difficult (Figure 10b), which is further exacerbated by the limited log information in the upper part of the outcrop due to accessibility difficulties. The additional information of the classified scan images resolve these problems and allow more reliable larger scale surface correlations to be made, although it is essential to use the log data as groundtruth in the correlation process. Along the correlation panel (orientated N-S) a percentage composition of facies proportions can be derived in the DOM. This is useful for looking for overall facies frequencies (Figure 10c) and potential for compositional variations with distance, although for the latter no significant variation can be described due to the relatively short observation scale of the provided example.

The classified point-cloud (Figure 7c) has other promising potential: calculating variograms, as the point-cloud dataset will give a much greater continuity of data than can be achieved with log data alone; as conditioning data during the facies modelling process in RMPs, going beyond the conventional well bore; and allow the generation of more accurate vertical and horizontal facies probabilistic curves.

\section{APPLICATIONS}

The case studies illustrate that digital outcrop studies have the potential to provide valuable additional information on these fluvial systems. The ability to view and model outcrops in three-dimensions give new perspectives on the data and allow measurements and interpretations to be made that are often unattainable in traditional outcrop studies. For example, in both case studies the DOMs made it possible to produce interpretations from normally inaccessible cliff sections. The spatial component of the DOMs in the OSF case study further offered the opportunity to analyze the interpretations and capture quantitative information on the characteristics of the sedimentary bodies (Figure 8). Traditional outcrop studies alone can only give a qualitative estimation on these characteristics as they lack a spatial component. In the Wolfville Formation case study the ability of the DOM to view the outcrop from different perspectives (e.g. view from above) provide the means to make more confident interpretations on the connection between faults. The faults can also be easily analyzed in the DOMs to obtain accurate orientations and length (e.g. mean, median, maximum).

The outcrop data in DOMs are further stored in a unified coordinate system. It makes the datasets easily available and transferable between geoscientists without corrupting the dataset, hence reducing errors. The geoscientists can use each other datasets for additional interrogation and analysis, make comparisons with subsurface and outcrop equivalents and as a valuable learning environment (e.g. in workshops, meetings, field courses).

DOMs can provide critical data needed in reservoir modelling of similar subsurface depositional systems. In order to simulate facies heterogeneity and analyze uncertainty in reservoir models, stochastic methods are applied to predict rock properties at unsampled locations (Dubrule and Damsleth 2001). However, to simulate the facies heterogeneity in a geologic realistic manner, stochastic facies modelling algorithms need to be driven by accurate 

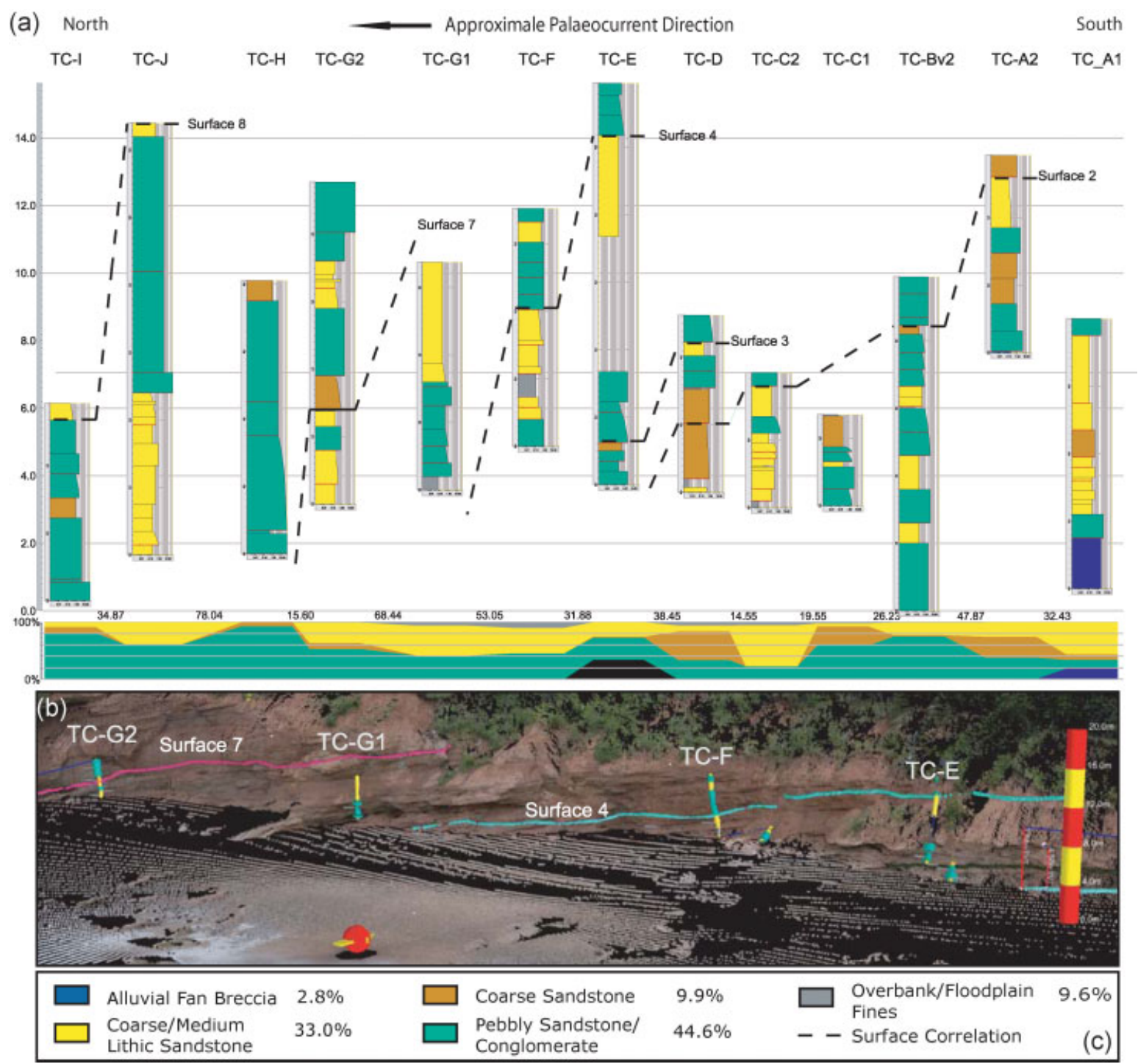

Figure 10. (a) Correlation panel of the Canadian Tennecape (Lower Wolfville Formation) study area, showing outcrop logs based on interpretations from the DOM, the logs are located in the correct relative elevation position and log spacing based on true distance between logs. (b) The DOM, with integrated logs and interpretations of key stratal surfaces. The interpretations are used to reduce the uncertainty in the correlation of the logs. (c) The facies key and derived facies frequencies from the log based correlation panel.

information on the depositional system (Falivene et al. 2006). Quantitative data, such as geometry and distribution of sedimentary bodies (Figures 8 and 10), derived from DOMs provide conditioning data for the algorithms to populate realistic subsurface geocellular reservoir models. In addition, detailed geocellular outcrop models derived from the DOMs can serve as a testing environment for geostatistical population methods, synthetic seismic modelling of subsurface seismic reflection patterns and fluid flow simulations to better understand flow behaviour in subsurface reservoirs (Adams et al. 2005; Janson et al. 2007).

Although there are many clear advantages, several disadvantages of the digital approach should to be considered before collecting and utilizing digital outcrop data. The method can be extremely labour intensive and time consuming and is done additionally to traditional outcrop studies. The digital acquisition of the outcrop data is overall relatively fast, however the data still requires to be groundtruthed by, for example, physical tracing of 

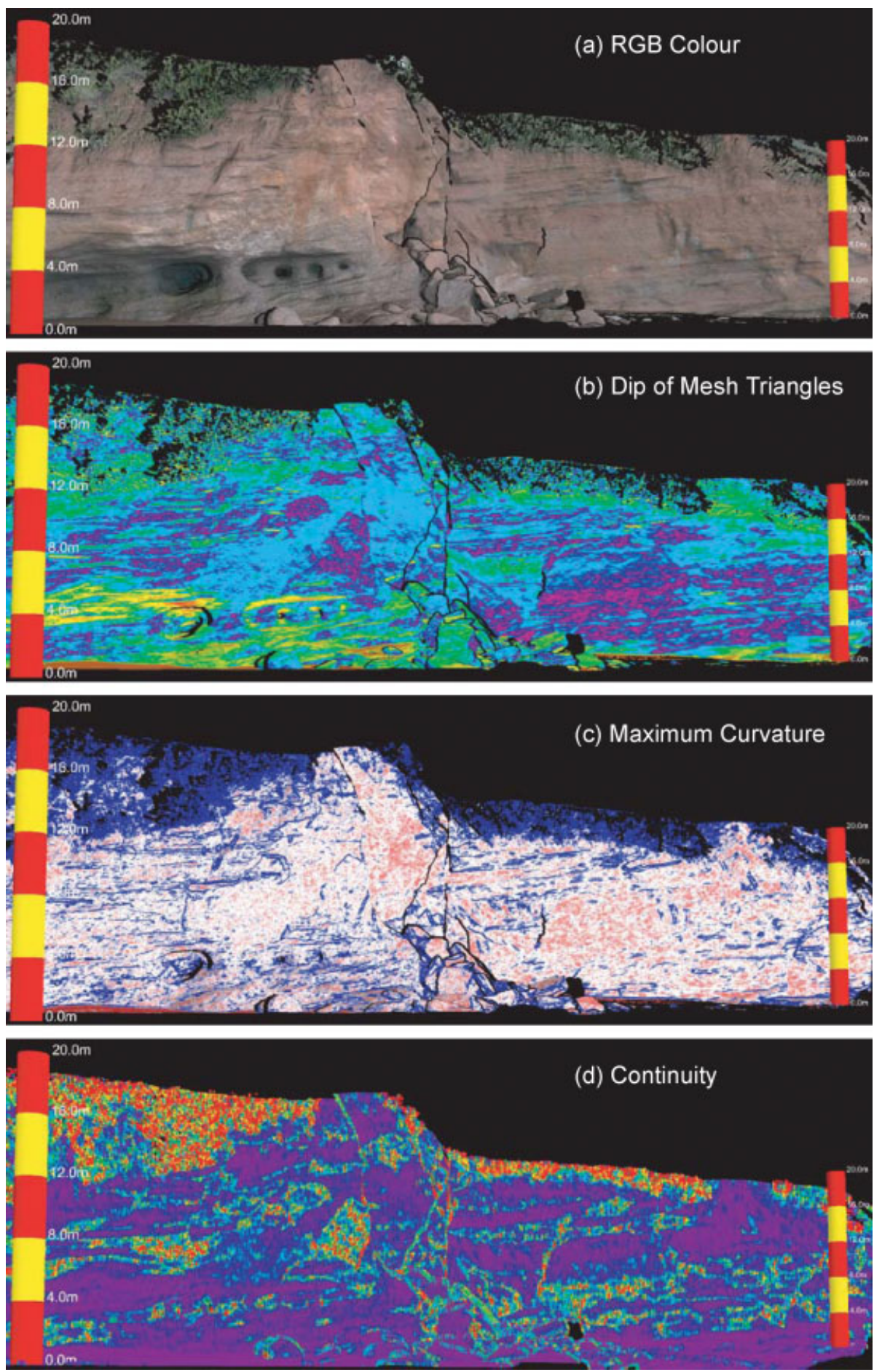

Figure 11. Attribute analysis of the Canadian Lower Wolfville Formation LiDAR data. (a) RGB Coloured mesh from digital photographs. (b) Dip of the triangles in the triangulated mesh ( $\mathrm{red}=$ low dip, blue $=$ high dip). (c) Maximum curvature of the mesh (red = low curvature, blue $=$ high curvature). (d) LiDAR data continuity based on range from scanner (red = low continuity picking out discontinuities such as faults, blue $=$ high continuity). 
surfaces, field measurements and photo-panel correlations. In addition, the post-processing and integration of the collected outcrop data into a unified coordinate system is often time consuming. Further issues arise about how to correctly analyze the outcrop data. Beside the problems in defining geological objects (Verwer 2008; Leleu and van Lanen 2009), development of specialized algorithms is often required to accurately analyze data (e.g. the surface building algorithm in VRGS). In order to build deterministic geocellular models of the DOMs cell sizes need to be sub-metre to metres scale. RMPs are, however, not developed to work with large amounts of small cells, which currently introduces computational difficulties in the population and manipulation of these geocellular outcrop models.

In order to resolve some of the above disadvantages several techniques are currently being developed. For example, an automated mapping technique to extract rock attributes based on intensity values (Adams et al. 2009) and bedding surfaces by shape extraction (Viseur et al. 2007). Another method under development uses an attribute analysis similar to that utilized in seismic data processing and image enhancement (Hodgetts 2009). The method extracts several attributes, like azimuth, dip and maximum curvature (Figure 11), from a surface mesh of the LiDAR dataset. The attributes offer various potential applications, such as automated mapping of bedding surfaces, faults and fractures and cleaning of the raw LiDAR dataset (vegetation and obscure point removal). For the Wolfville Formation dataset the attribute analysis allows easy picking of fault/fracture planes which are highlighted as areas of uniform dip and low curvature when exposed as planes in the LiDAR dataset (Figure 11b, c). Another form of processing is based on comparing consecutive vertical scan lines to look for correlation from one line to the next in a similar manner to continuity or coherence parameter in seismic data (Bahorich and Farmer 1995; Bacon et al. 2003), the result of this are shown in Figure 11d. This highlights variation across the outcrop, e.g. termination of bedding planes at a fault, and so helps identify faults that are perpendicular to the outcrop and expressed as fault traces.

\section{CONCLUSIONS}

The two case studies demonstrate how high-resolution spatial data and traditional geological observation of sedimentary architecture and structures can be integrated to produce DOMs. The digital studies provide valuable additional outcrop observations and allow interpretation that would have been difficult or impossible to make from traditional outcrop studies alone.

Much focus has been placed in recent years on digitally capturing outcrop data, but how to analyze the entire datasets and obtain quantitative information on, for example, the sedimentary architecture still needs to be addressed (Verwer 2008). In this paper, several analysis techniques are presented which provide statistical information from real observations. The OSF case study illustrates a technique to extract geostatistical information on the dimension of sedimentary bodies from the DOM (Fabuel-Perez et al. 2009a). This approach is being extended in the Wolfville Formation case study by the inclusion of the point-cloud classification and developing improved workflows and techniques to better integrate sedimentary logs and correlation panels. The georeferencing of all data into a uniform coordinate system allows improved analysis of data, and provides a framework for detailed interpretation. Additionally, the DOM provides an effective database for data storage (digital photographs, samples IDs and locations etc), and makes adding and storing new data easy and transferable between geoscientists.

The Wolfville Formation dataset further illustrates how the DOM can provide additional information on structure and sedimentology, allowing an integrated geological model including both structure and sedimentology to be analyzed in equal detail depending on the needs of the project. As the dataset is fully georeferenced a DOM can be taken back in the field using a field ruggedized laptop with integrated GPS and new data can be recorded directly in the field into the DOM. It further may be used as a replacement for the traditional field basemap. This is currently possible, though the limiting factors are still hardware based (quality of screens, battery life, accuracy of touchscreens etc.).

These DOM based approaches are leading to the improved collection of various statistical parameters for different depositional environments. The larger datasets provide more statistically significant information of object 
geometries and distribution, as well as the potential to calculate more accurate variograms through being able to utilize more continuous information. These geostatistical datasets can than be used to provide constraints for stochastic modelling (pixel and object based methods) approaches to generate more realistic subsurface geocellular reservoir models of the depositional environment.

\section{ACKNOWLEDGEMENTS}

The authors thank the North Africa Research Group (NARG) consortium and Shell EPTS for providing funding of respectively the Moroccan and Canadian case studies. Adam Robinson and Colin North are thanked for their constructive comments and suggestions that greatly improved the manuscript. Also acknowledged are also Sophie Leleu and Frank Rarity for their support in the field and fruitful discussions. Finally, Tom McKie and Brian Williams are thanked for their encouragements, suggestions and patience.

\section{REFERENCES}

Adams EW, Bellian JA, Milroy P, Reyes R. 2009. Supervised automated lidar mapping of Permo-Triassic strata, Jebel Akhdar, Oman. In American Association of Petroleum Geologists Annual Convention. Denver (CO), USA; 2-3.

Adams EW, Grotzinger JP, Watters WA, Schroder S, McCormick DS, Al-Siyabi HA. 2005. Digital characterization of thrombolitestromatolite reef distribution in a carbonate ramp system (terminal Proterozoic, Nama Group, Namibia). American Association of Petroleum Geologists Bulletin 89: 1293-1318.

Alexander J. 1993. A discussion on the use of analogues for reservoir geology. In Advances in Reservoir Geology, Ashton M (ed.). Geological Society, London, Special Publication 69; 175-194.

Bacon M, Simm R, Redshaw T. 2003. 3D Seismic Interpretation. Cambridge University Press, Cambridge: 212p.

Bahorich M, Farmer S. 1995. 3-D seismic discontinuity of faults and stratigraphic features: the coherence cube. The Leading Edge 14: 10531058.

Bates KT, Rarity F, Manning PL, Hodgetts D, Villa B, Oms O, Galobart A, Gawthorpe RL. 2008. High-resolution LiDAR and photogrammetric survey of the Fumanya dinosaur tracksites (Catalonia): implications for the conservation and interpretation of geological heritage sites. Journal of the Geological Society of London 165: 115-127.

Bellian JA, Kerans C, Jennette DC. 2005. Digital outcrop models: applications of terrestrial scanning LiDAR technology in stratigraphic modeling. Journal of Sedimentary Research 75: 166-176.

Benaouiss N, Courel L, Beauchamp J. 1996. Rift-controlled fluvial/tidal transitional series in the Oukaimeden Sandstones, High Atlas of Marrakesh (Morocco). Sedimentary Geology 107: 21-36.

Biron P, Courtinat B. 1982. Palynological contribution to the knowledge of Triassic High Atlas of Marrakech, Morocco. Geobios (Villeurbanne) 15: 231-236.

Bond CE, Shipton ZK, Jones RR, Butler RWH, Gibbs AD. 2007. Knowledge transfer in a digital world: field data acquisition, uncertainty, visualization, and data management. Geosphere 3: 568-576.

Bristow CS, Best JL. 1993. Braided rivers: perspectives and problems. In Braided Rivers, Best JL, Bristow CS (eds). Geological Society, London, Special Publication 75; 1-11.

Bryant ID, Flint SS. 1993. Quantitative clastic reservoir geological modelling: problems and perspectives. In The Geological Modelling of Hydrocarbon Reservoirs and Outcrop Analogues, Bryant ID, Flint SS (eds). International Association of Sedimentologists, Special Publication 15; 3-20.

Buckley SJ, Howell JA, Enge HD, Kurz TH. 2008. Terrestrial laser scanning in geology: data acquisition, processing and accuracy considerations. Journal of the Geological Society of London 165: 625-638.

Caers JF, Zhang T. 2004. Multiple-point geostatistics: a quantitative vehicle for integrating geologic analogs into multiple reservoir models. In Integration of Outcrop and Modern Analogs in Reservoir Modeling, Grammer GM, Harris PM, Eberli GP (eds). American Association of Petroleum Geologists Memoir 80; 1-22.

Corbeanu RM, Soegaard K, Szerbiak RB, Thurmond JB, McMechan GA, Wang D, Snelgrove S, Forster GB, Menitove A. 2001. Detailed internal architecture of a fluvial channel sandstone determined from outcrop, cores, and 3-D ground-penetrating radar: example from the middle Cretaceous Ferron Sandstone, east-central Utah. American Association of Petroleum Geologists Bulletin 85: $1583-1608$.

Doherty PD, Soreghan GS, Castagna JP. 2005. Outcrop-based reservoir characterization: a composite phylloid-algal mound, western Orogrande basin (New Mexico). American Association of Petroleum Geologists Bulletin 86: 779-795.

Dubrule O, Damsleth E. 2001. Achievements and challenges in petroleum geostatistics. Petroleum Geoscience 7: 51-57.

Enge HD, Buckley SJ, Rotevatn A, Howell JA. 2007. From outcrop to reservoir simulation model: workflow and procedures. Geosphere 3: 469-490.

Engelkemeir RM, Khan SD. 2008. Lidar mapping of faults in Houston, Texas, USA. Geosphere 4: 170-182. 
Fabuel-Perez I, Hodgetts D, Redfern J. 2009a. A new approach for outcrop characterization and geostatistical analysis of a low-sinuosity fluvial-dominated succession using digital outcrop models: Upper Triassic Oukaimeden Sandstone Formation, central High Atlas, Morocco. American Association of Petroleum Geologists Bulletin 93: 795-827.

Fabuel-Perez I, Redfern J, Hodgetts D. 2009b. Sedimentology of an intra-montane rift-controlled fluvial dominated succession: the Upper Triassic Oukaimeden Sandstone Formation, Central High Atlas, Morocco. Sedimentary Geology 218: 103-140.

Falivene O, Arbues P, Howell JA, Munoz JA, Fernandez O, Marzo M. 2006. Hierarchical geocellular facies modelling of a turbidite reservoir analogue from the Eocene of the Ainsa basin, NE Spain. Marine and Petroleum Geology 23: 679-701.

Friend PF, Slater MJ, Williams RC. 1979. Vertical and lateral building of river sandstone bodies, Ebro basin, Spain. Geological Society of London 136: 39-46.

Grammer GM, Harris PM, Eberli GP. 2004. Integration of outcrop and modern analogs in reservoir modeling: overview with examples from the Bahamas. In Integration of Outcrop and Modern Analogs in Reservoir Modeling, Grammer GM, Harris PM, Eberli GP (eds). American Association of Petroleum Geologists Memoir 80; 1-22.

Hodgetts D. 2009. Geological applications. In Laser Scanning for the Environmental Sciences, Heritage G, Large A (eds). Wiley-Blackwell, Chichester; 165-180.

Hodgetts D, Drinkwater NJ, Hodgson J, Kavanagh J, Flint SS, Keogh KJ, Howell JA. 2004. Three-dimensional geological models from outcrop data using digital data collection techniques: an example from the Tanqua Karoo depocentre, South Africa. In Geological Prior Information: Informing Science and Engineering, Curtis A, Wood R (eds). Geological Society, London, Special Publication $239 ; 57-75$.

Hodgetts D, Gawthorpe RL, Wilson P, Rarity F. 2007. Development of Virtual Reality Geological Studio (VRGS): integrating lidar, DGPS and traditional field techniques. In From Outcrop to Asset Conference: recent advances in digital outcrop data collection and modelling techniques. Manchester, England

Hubert JF, Forlenza MF. 1988. Sedimentology of braided-river deposits in Upper Triassic Wolfville redbeds, southern shore of Cobequid Bay, Nova Scotia, Canada. In Triassic-Jurassic Rifting: Continental Breakup and the Origin of the Atlantic Ocean and Passive Margins, Manspeizer W (ed.). Elsevier: Amsterdam; 231-247.

Hubert JF, Mertz KA. 1980. Eolian dune field of Late Triassic age, Fundy Basin, Nova Scotia. Geology 8: 516-519.

Hubert JF, Mertz KA. 1984. Eolian sandstones in Upper Triassic-Lower Jurassic red beds of the Fundy Basin, Nova Scotia. Journal of Sedimentary Petrology 54: 798-810.

Janson X, Kerans C, Bellian JA, Fitchen W. 2007. Three-dimensional geological and synthetic seismic model of Early Permian redeposited basinal carbonate deposits, Victorio Canyon, west Texas. American Association of Petroleum Geologists Bulletin 9: 1405-1436.

Jones RR, McCaffrey KJW, Imber J, Wightman R, Smith SAF, Holdsworth RE, Glegg P, De Paola N, Healy D, Wilson RW. 2008b. Calibration and validation of reservoir models: the importance of high resolution, quantitative outcrop analogues. In The Future of Geological Modelling in Hydrocarbon Development, Robinson A, Griffiths P, Price S, Hegre J, Muggeridge A (eds). The Geological Society, London, Special Publications 309; 87-98.

Jones RR, McCaffrey KJW, Wilson RW, Holdsworth RE. 2004. Digital field data acquisition: towards increased quantification of uncertainty during geological mapping. In Geological Prior Information: Informing Science and Engineering, Curtis A, Wood R (eds). Geological Society, London, Special Publication, 239; 43-56.

Jones RR, Pringle JK, McCaffrey KJW, Reynolds T, Wightman R, Long J. 2008a. Extending virtual outcrop geology into the subsurfacecombining terrestrial laser scanning and ground penetrating radar at the Bridge of Ross, Co. Clare. In SEPM Research Conference: Outcrops Rivitalized: Tools, Techniques and Applications. Kilkee, County Clare: Ireland, 27.

Labourdette R, Jones RR. 2007. Characterization of fluvial architectural elements using a three-dimensional outcrop data set: Escanilla braided system South-Central Pyrenees, Spain. Geosphere 3: 422-434.

Leleu S, van Lanen XMT. 2009. Braided rivers: a limit to depositional models. In From River to Rock Record Conference. Aberdeen, Scotland; 56.

Leleu S, Hartley AJ, Williams BPJ. 2009. Large-scale alluvial architecture and correlation in a Triassic pebbly braided river system, Lower Wolfville Formation (Fundy Basin, Nova Scotia, Canada). Journal of Sedimentary Research 79: 265-286.

Manspeizer W. 1988. Triassic-Jurassic rifting and opening of the Atlantic: an overview. In Triassic-Jurassic Rifting: Continental Breakup and the Origin of the Atlantic Ocean and Passive Margins, Manspeizer W (ed.). Elsevier: Amsterdam; 41-79.

Manspeizer W, Puffer JH, Cousminer HL. 1978. Separation of Morocco and eastern North America: a Triassic record. Geological Society of America Bulletin 89: 901-921.

Martin JH. 1993. A review of braided fluvial hydrocarbon reservoirs: the petroleum engineer's perspective. In Braided Rivers, Best JL, Bristow CS (eds). Geological Society, London, Special Publication 75; 333-367.

Mattis AF. 1977. Non marine Triassic sedimentation, central High Atlas, Morocco. Journal of Sedimentary Petrology 47: 107-119.

McCaffrey KJW, Jones RR, Holdsworth RE, Wilson RW, Clegg P, Imber J, Holliman N, Trinks I. 2005. Unlocking the spatial dimension: digital technologies and the future of geoscience fieldwork. Journal of the Geological Society of London 162: 1-2.

McCormick DC, Irving DHB, Brocklehurst SH, Rarity F. 2008. Glacial geomorphological mapping of Coire Mhic Fhearchair, NW Scotland: the contribution of a high-resolution ground-based LiDAR survey. Journal of Maps 315-331.

Miall AD, Tyler N. 1991. The three-dimensional facies architecture of terrigenous clastic sediments and its implications for hydrocarbon discovery and recovery: Concepts in sedimentology and paleontology. 3: Tulsa, SEPM, 309.

North CP, Prosser DJ. 1993. Characterization of fluvial and aeolian reservoirs: problems and approaches. In Characterization of Fluvial of Aeolian Reservoirs, North CP, Prosser DJ (eds). Geological Society, London, Special Publication 73; 1-6.

Olariu MI, Ferguson JF, Aiken CLV, Xu X. 2008. Outcrop fracture characterization using terrestrial laser scanners: deep-water Jackfork sandstone at Big Rock Quarry, Arkansas. Geosphere 4: 247-259.

Olsen PE. 1997. Stratigraphic record of the Early Mesozoic breakup of Pangea in the Laurasia-Gondwana rift system. Annual Review of Earth and Planetary Sciences 25: 337-401.

Olsen PE, Kent DV, Fowell SJ, Schlische RW, Withjack MO, LeTourneau PM. 2000. Implications of a comparison of stratigraphy and depositional environments of the Argana (Morocco) and Fundy (Nova Scotia, Canada) Permian-Jurassic basins. In Le Permien et le Trias du 
Maroc, Actes de la Premier Reunion su Groupe Marocain du Permien et du Trias, Oujidi M, Et-Touhami M (eds). Hilal Impression: Oujda; $165-183$.

Olsen PE, Schlische RW, Gore PJW. 1989. Tectonic, depositional and paleoecological history of the Early Mesozoic rift basins, eastern North America: Field Trip Guidebook American Geophysical Union T351 Washington, 174.

Petit JP, Beauchamp J. 1986. Synsedimentary faulting and palaeocurrent patterns in the Triassic sandstones of the High-Atlas (Morocco). Sedimentology 33: 817-829.

Phelps RM, Kerans C. 2007. Architectural characterization and three-dimensional modeling of a carbonate channel-levee complex: Permian San Andres Formation, Last Chance Canyon, New Mexico, USA. Journal of Sedimentary Research 77: 939-964.

Phelps RM, Kerans C, Scott SZ, Janson X, Bellian JA. 2008. Three-dimensional modelling and sequence stratigraphy of a carbonate ramp-toshelf transition, Permian Upper San Andres Formation. Sedimentology 55: 1777-1813.

Pringle JK, Howell JA, Hodgetts D, Westerman AR, Hodgson DM. 2006. Virtual outcrop models of petroleum reservoir analogues: a review of the current state-of-the-art. First Break 24: 33-42.

Taj-Eddine K, Pignone R. 2005. L'Ourika: Haut Atlas-Haouz de Marrakech, Maroc. Un patrimoine geologique, biologique et culturel exceptionnel. Scale 1:60.000, Florence: SELCA.

Verwer K. 2008. Spatial models of carbonate platform anatomy. Ph.D Thesis, Vrije Universiteit Amsterdam.

Verwer K, Adams EW, Kenter JAM. 2007. Digital outcrop models: technology and applications. First Break 25: 57-63.

Verwer K, Della Porta G, Merino-Tome O, Kenter JAM. 2009b. Controls and predictability of carbonte facies architecture in a Lower Jurassic three-dimensional barrier-shoal complex (Djebel Bou Daha, High Atlas, Morocco). Sedimentology 56: 1801-1831.

Verwer K, Kenter JAM, Drijkoningen GG, Braaksma H, Filippidou A. 2004b. Geology and geophysics: groundtruthing through natural seismic observatories. In EGU General Assembly. Nice, France; 213.

Verwer K, Kenter JAM, Maathuis B, Della Porta G. 2004a. Stratal patterns and lithofacies of an intact seismic-scale Carboniferous carbonate platform (Asturias, northwestern Spain): a virtual outcrop model. In Geological prior information: informing science and engineering, Curtis A, Wood R (eds). Geological Society, London, Special Publication 239; $29-41$.

Verwer K, Merino-Tome O, Kenter JAM, Della Porta G. 2009a. Evolution of a high-relief carbonate platform using 3D digital outcrop models: Lower Jurassic Djebel Bou Dahar, High Atlas, Morocco. Journal of Sedimentary Research 79: 416-439.

Viseur S, Richet R, Borgomano J, Adams EW. 2007. From 3D virtual outcrops to 3D carbonates facies models: The lower Cretaceous of the Vercors, Southern France. In From Outcrop to Asset Conference: Recent Advances in Digital Outcrop Data Collection and Modelling Techniques. Manchester, England

Wade JA, Brown DE, Traverse A, Fensome RA. 1996. The Triassic-Jurassic Fundy Basin, Eastern Canada: regional setting, stratigraphy and hydrocarbon potential. Atlantic Geology 32: 189-231.

Wawrzyniec TF, McFadden LD, Ellwein A, Meyer G, Scuderi L, McAuliffe J, Fawcett P. 2007. Chronotopographic analysis directly from point-cloud data: a method for detecting small, seasonal hillslope change, Black Mesa Escarpment, NE Arizona. Geosphere 3: $550-567$.

Wilson P, Hodgetts D, Rarity F, Gawthorpe RL, Sharp IR. 2009. Structural geology and 4D evolution of a half-graben: new digital outcrop modelling techniques applied to the Nukhul half-graben, Suez rift, Egypt. Journal of Structural Geology 31: 328-345. 